\title{
Classification Systems in Rotator Cuff Tears
}

\author{
Ram Chidambaram ${ }^{1}$, Reet Mukhopadhyay ${ }^{2}$
}

\section{Abstract}

Rotator cuff pathology is one of the most common conditions affecting the shoulder joint. Several classification systems have been used to describe rotator cuff tears in orthopedic literature. However, no comprehensive classification inclusive of all types and characteristics currently exists. Rotator cuff tears are classified based on various parameters. These include: 1. Tear depth 2. Tear Size/Extent 3. Tear Retraction 4. Tendon Quality 5. Tear Progression 6. Arthroscopic Classification. This review article aims to establish an algorithm based on the various existing classification systems so as to arrive at the best surgical or non-surgical solution as well as prognosticate the patient regarding the outcome. Special consideration needs to be made for massive tears which are irreparable.

Keywords: Rotator cuff tears; Rotator cuff tear classification; Massive irreparable rotator cuff tears; Partial rotator cuff tears; Subscapularis tears; Geometric Classification; Arthroscopic Classification; Rotator cuff retraction; Rotator cuff tendon quality; Prognosis for Rotator Cuff tears.

\section{Introduction}

Rotator cuff pathology is one of the most common conditions affecting the shoulder joint. Results after surgical management in rotator cuff pathology are good in most cases. It is therefore important to accurately diagnose the pathology and the extent of rotator cuff damage as well as adequately prognosticate the functional recovery of the patient. Several classification systems have been used to describe rotator cuff tears in orthopaedic literature. However, there exists no comprehensive classification that includes all the types and characteristics of rotator cufftears.

\section{Classification}

Any classification system should be

1) Easily understandable amongst surgeons

2) Easily applicable in day-to-day practice

3) Reproducible and communicable

4) Able to identify the pathology and guess prognosis

5) Allow surgeons to arrive at the best surgical or non-surgical solution

6) Help clinicians to compare their outcome on operated patients Rotator cuff tears are classified based on various parameters These include:

1. Tear depth

2. TearSize/Extent

3. Tear Retraction

4. Tendon Quality

5. Tear Progression

6. Arthroscopic Classification

\section{Tear Depth}

Partial rotator cufflesions are not always included in most classification systems. In 1990, Ellman [1] described partial rotator cuff lesions and classified them based on the location and depth of the tear (Table 1). Considering the average thickness of the rotator cuff tendon near insertion as $12 \mathrm{~mm}$, he chose a cut-off point of $6 \mathrm{~mm}$ to segregate them into low grade and high-grade tears. He emphasised that rotator cuff lesions begin as a tendinopathy and that articular sided tears are more common than bursal sided tears. Partial tears tend to progress to full thickness lesions ifleft untreated.

However, the actual measurement of cuff tear thickness can vary as there is always subjective measurement error during both MRI and surgery.

\section{TearSize/Extent}

Classification on extent should be based on (i) size of the tear and (ii) number of tendons involved. In 1984, Deorio and Cofield classified rotator cuff tears as small, medium, large or massive based on the length of the maximum diameter of tear. However, analysis has to be done in a 3-dimensional manner to avoid underestimating the size of the tear. In 2020, Davidson et al [2] proposed a geometric classification based on preoperative $\mathrm{T} 2$ weighted sagittal and coronal MRI sections (Table 2 ). It can alert the surgeon about the cuff tear size (antero-posterior as well as medio-lateral), geometric pattern, prognosis and the surgical repair needed.

Regarding the number of tendons involved, Patte [3] established a comprehensive classification system in 1990 dividing the rotator cuff

${ }^{1}$ Department of Shoulder, Elbow, Hand and Sports Injuries, MGM Healthcare, Aminjikarai, Chennai, Tamil Nadu, India.

${ }^{2}$ Department of Orthopaedics, R.G.Kar Medical College \& Hospital, Kolkata, West Bengal, India.

Address of Correspondence:

Dr. Reet Mukhopadhyay,

Department of Orthopaedics, R.G.Kar Medical College \& Hospital, Kolkata, West Bengal, India.

E-mail: reetm.2008@gmail.com

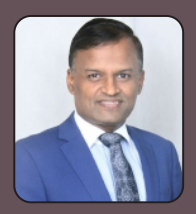

Dr. Ram Chidambaram

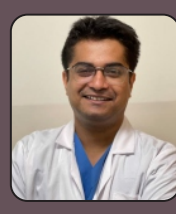

Dr. Reet Mukhopadhyay

Submitted: 10 February 2021; Reviewed: 01 April 2021; Accepted: 25 April 2021; Published: 10 June 2021

Asian Journal of Arthroscopy | ISSN 2456-1169| Available on www.asianarthroscopy.com | DOI:10.13107/aja.2021.v06i01.022 |

This is an open access journal, and articles are distributed under the terms of the Creative Commons Attribution Non-Commercial-Share Alike 4.0 License (http://creativecommons.org/licenses/by-nc-sa/4.0) which allows others to remix, tweak, and build upon the work non-commercially as long as appropriate credit is given and the new creation are licensed under the identical terms. 
lesion into 6 segments. Similarly, Habermeyer et al classified the tear based on sagittal plane topography into 3 distinct zones, reflecting the number of tendons involved. However, in 2014, Collin [4] et al classified the rotator cuff tear into 5 zones based on functional impairment and development of pseudoparalysis (Table 3, Figure 1). They showed that loss of subscapularis function is crucial in the development of pseudoparalysis. This classification is deemed to be more useful as it correlates clinically with the range of motion.

In 2007, Lafosse [5] et al classified subscapularis tears according to their extent (Table 4). This serves as a good tool in guiding treatment for rotator cuff lesions involving subscapularis tears as well. Subscapularis tears are found in 59\% of cases with rotator cuff and are also frequently associated with lesion or tear of the long head of the biceps tendon. By dividing the subscapularis tears into superior two-thirds and complete, the classification highlights a similar finding to that of Collin et al who proposed the name "Subscapularis Minor" [4] to the inferior third of the muscle. The distinction in the anatomy, function and even nerve supply of the superior and inferior portions of the muscle make this a useful classification.

\begin{tabular}{|c|c|c|c|c|c|c|}
\hline \multicolumn{7}{|c|}{ |Table 1: Ellman's Classification } \\
\hline & Location & \multicolumn{2}{|c|}{ Grade } & \multicolumn{3}{|c|}{ Area of Defect } \\
\hline & Articular & \multicolumn{2}{|c|}{ 1. $<3 \mathrm{~mm}$ deep } & \multicolumn{3}{|c|}{ Base of tear* area of retraction $=\mathrm{mm}^{2}$} \\
\hline & B. Bursal & \multicolumn{2}{|c|}{ 2. $3-6 \mathrm{~mm}$ deep } & & & \\
\hline \multicolumn{2}{|r|}{ C. Interstitial } & \multicolumn{2}{|c|}{ 3. $>6 \mathrm{~mm}$ deep } & & & \\
\hline \multicolumn{2}{|r|}{ Grade } & \multicolumn{2}{|c|}{ Treatment } & \multicolumn{3}{|c|}{ Prognosis } \\
\hline \multicolumn{2}{|c|}{ 1. $<3 \mathrm{~mm}$ deep } & \multicolumn{2}{|c|}{ NSAIDS, Physiotherapy } & \multicolumn{3}{|c|}{ Excellent with non-operative } \\
\hline & 3-6 $\mathrm{mm}$ deep & \multicolumn{2}{|c|}{ Debridement + /- Repair } & \multicolumn{3}{|c|}{ Good to excellent with surgery } \\
\hline & $>6 \mathrm{~mm}$ deep & \multicolumn{2}{|c|}{ Surgical Repair } & \multicolumn{3}{|c|}{ Poor with non-operative } \\
\hline \multicolumn{7}{|c|}{ Table 2: Geometric Classification } \\
\hline Type & Description & $\begin{array}{l}\text { Pre-MRI } \\
\text { findings }\end{array}$ & Mobilit & & Treatment & Prognosis \\
\hline 1 & Crescent & Short and wide & \multicolumn{3}{|c|}{$\begin{array}{l}\text { Excellent (medicl End-to- bone } \\
\text { to lateral) }\end{array}$} & $\begin{array}{l}\text { Good to } \\
\text { excellent }\end{array}$ \\
\hline 2 & $\begin{array}{l}\text { Longitudinal } \\
\text { (L- or U- } \\
\text { shaped) }\end{array}$ & $\begin{array}{l}\text { Long and } \\
\text { narrow }\end{array}$ & \multicolumn{2}{|c|}{$\begin{array}{l}\text { Excellent } \\
\text { (Anterior to } \\
\text { posterior) }\end{array}$} & $\begin{array}{c}\text { Margin } \\
\text { Convergence }\end{array}$ & $\begin{array}{l}\text { Good to } \\
\text { excellent }\end{array}$ \\
\hline 3 & $\begin{array}{l}\text { Massive } \\
\text { Contracted }\end{array}$ & $\begin{array}{l}\text { Long and wide } \\
\quad>2 * 2 \mathrm{~cm}\end{array}$ & \multicolumn{2}{|c|}{ Minimal } & $\begin{array}{l}\text { Interval Slides } \\
\text { or Partial Repair }\end{array}$ & Fair to Good \\
\hline 4 & $\begin{array}{l}\text { Cuff Tear } \\
\text { Arthropathy }\end{array}$ & $\begin{array}{l}\text { Cuff Tear } \\
\text { Arthropathy }\end{array}$ & \multicolumn{2}{|l|}{ NA } & Arthroplasty & Fair to Good \\
\hline \multicolumn{7}{|c|}{ Table 4: Lafosse's Classification of Subscapularis Tear } \\
\hline Type & \multicolumn{2}{|c|}{ Lesion } & \multicolumn{4}{|c|}{ Remarks } \\
\hline I & \multicolumn{2}{|c|}{$\begin{array}{c}\text { Partial lesion of superior one- } \\
\text { third }\end{array}$} & \multirow{5}{*}{\multicolumn{4}{|c|}{$\begin{array}{l}\text { 1) Arthroscopic subscapularis repair is } \\
\text { durable with reduceosostoperativestiffness } \\
\text { (compared to open) } \\
\text { 2) Type V lesions are not candidates for } \\
\text { repair. Tendon transfer or arthroplasty are } \\
\text { better options. } \\
\text { 3) Biceps tenotomy or tenodesis is } \\
\text { recommended even in absence of lesion in the } \\
\text { long head of the biceps tendon in case of } \\
\text { subscapularis lesion. }\end{array}$}} \\
\hline II & \multicolumn{2}{|c|}{$\begin{array}{c}\text { Complete lesion of superior } \\
\text { one-third }\end{array}$} & & & & \\
\hline III & \multicolumn{2}{|c|}{$\begin{array}{l}\text { Complete lesion of superio: } \\
\text { two-thirds }\end{array}$} & & & & \\
\hline IV & \multicolumn{2}{|c|}{$\begin{array}{l}\text { Complete lesion of tendon. } \\
\text { Head eccentric (Subcoracoid } \\
\text { Impingement); Fatty } \\
\text { degeneration }>\text { Grade } 3\end{array}$} & & & & \\
\hline $\mathrm{V}$ & $\begin{array}{r}\text { Complete } \\
\text { Head eccent } \\
\text { Imping } \\
\text { degenera }\end{array}$ & $\begin{array}{l}\text { lesion of tendon. } \\
\text { tric (Subcoracoid } \\
\text { fement); Fatty } \\
\text { tion }>\text { Grade } 3\end{array}$ & & & & \\
\hline
\end{tabular}

\section{Tear Retraction}

In 1990, Patte [3] reported that the classification of rotator cuff lesions needed to take into account (1) the extent of the tear, (2) topography of the tear in the sagittal and frontal plane, (3)the status of the muscle and (4) long head of biceps tendon. While the classification of extent and sagittal plane topography has largely been replaced by better classification systems, the frontal plane topography describes the extent of retraction as well as the amount of necrosis in the proximal stump, remaining as one of the most popular classification systems of rotator cuff tears (Table 5, Figure 2).

\section{Tendon Quality}

In 1994, Goutallier et al [6] devised a grading system to evaluate the quality of rotator cuff tendons based on fatty infiltration into the muscle mass using CT scan (Table 6). They concluded that fatty degeneration of muscle results in loss of strength and loss in range of motion. They found that infraspinatus in wide antero-superior cuff tears underwent fatty degeneration despite having no tear. The mean time for progression from tear to Grade 2 fatty infiltration was three years for supraspinatus and two and a half years for infraspinatus and subscapularis.

With increasing use and popularity of MRI, Fuchs et al [7] in 1999 validated the same system using sagittal and coronal images. Zanetti, Gerber and Hodler [8] described the "tangent sign" on sagittal sections of MRI to evaluate the fatty infiltration within supraspinatus muscle

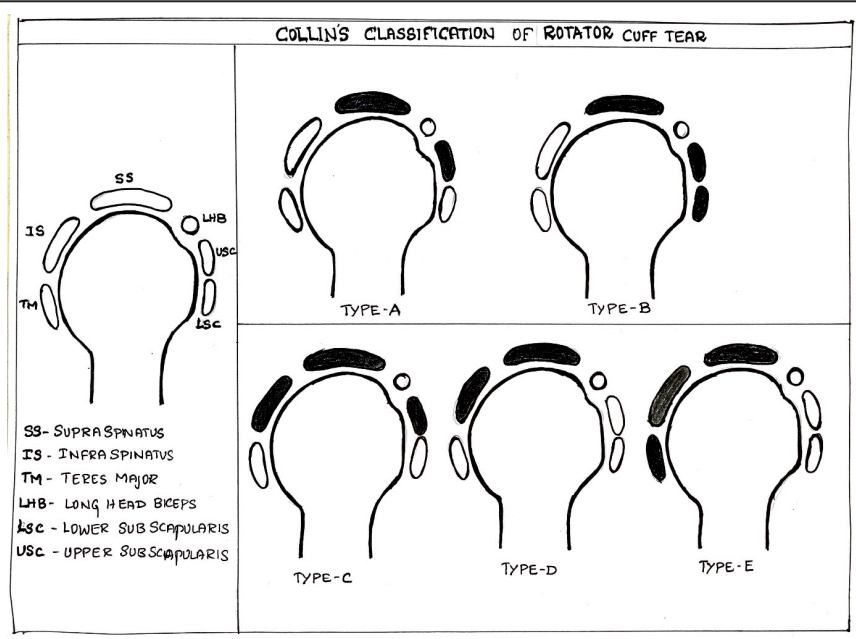

Figure 1: Collins's classification of Rotator Cuff Tear

\section{Table 3: Collin's Classification}

\begin{tabular}{|c|c|c|}
\hline Type & Description & \multirow{7}{*}{$\begin{array}{l}\text { Remarks } \\
\text { 1) Loss of subscapularis function is } \\
\text { crucial for developing } \\
\text { pseudoparalysis*. } \\
\text { 2) Loss of } 3 \text { rotator cuff muscles } \\
\text { increases chances of pseudoparalysis } \\
\text { 3) There is differential role of } \\
\text { infraspinatus and teres minor in } \\
\text { external rotation (Infraspinatus- } \\
\text { External rotation in adducted position } \\
\text { Teres Minor- External rotation in } \\
\text { abducted position) } \\
\text { ctive anterior elevation with full passive } \\
1 \text { impairment [4]. }\end{array}$} \\
\hline Type A & $\begin{array}{l}\text { Supraspinatus and superior } \\
\text { Subscapularis type }\end{array}$ & \\
\hline Type B & $\begin{array}{l}\text { Supraspinatus and entire } \\
\text { Subscapularis type }\end{array}$ & \\
\hline Type C & $\begin{array}{l}\text { Supraspinatus, superior } \\
\text { Subscapularis and } \\
\text { infraspinatus }\end{array}$ & \\
\hline Type D & Supra- a & \\
\hline Type E & $\begin{array}{l}\text { Supraspinatus, infraspinatus } \\
\text { and teres minor }\end{array}$ & \\
\hline \multicolumn{2}{|c|}{$\begin{array}{l}\text { *Pseudoparalysis- defined as }<90^{\circ} \text { active anterior elevation with full passive } \\
\text { range of motion without neurological impairment [4]. }\end{array}$} & \\
\hline
\end{tabular}




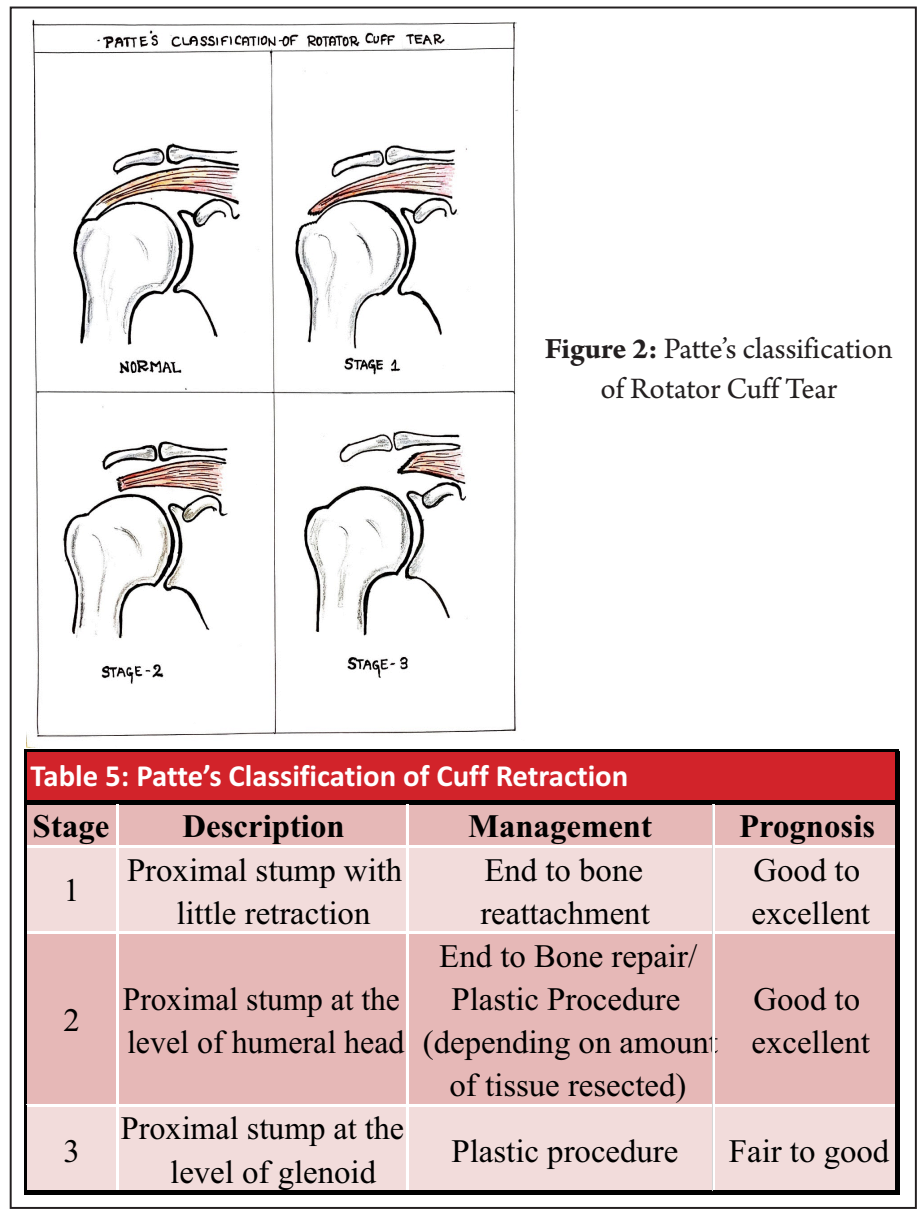

mass as an indicator for repairability of the rotator cuff tear.

Thomazeau et al [9] in 1994 proposed an "occupancy ratio" of the supraspinatus fossa to the supraspinatus muscle mass (Table 7). They describe muscle atrophy and fatty infiltration as different expressions for the same pathology.

\section{Tear Progress}

Neer et al [20] first described Cuff tear arthropathy in 1997. Hamada et al [21] then described the progression of massive rotator cuff tears based on radiographic findings (Table 8 ). They also gave a pathomechanical explanation for the progression of rotator cuff arthropathy. In the absence of rotator cuff function, deltoid contraction causes superior migration of the humeral head. This increases the stress on the long head of the biceps tendon, causing it to tear. As the superior migration increases, there is gradual "acetabulization" of the acromion process. Although the Hamada classification is chiefly of historical importance and is mostly in use to plan reverse shoulder arthroplasties in current times [10], it remains a useful classification system in day-today practice. It helps to differentiate joint preserving procedure and arthroplasty in a case of massive rotator cuff tear.

\section{Arthroscopic Classification}

Once the rotator cuff lesion has been assessed clinically and radiologically, a diagnostic arthroscopy provides the best method for confirming and classifying the tear pattern and characteristics. The geometric classification of Davidson et al [2] for pre-operative MRI is also applicable arthroscopically. Once the portals are established, the antero-posterior and medio-lateral mobility is assessed. This helps to

\section{Table 6: Goutallier's classification on muscle fatty infiltration}

Grade Description Remarks

$0 \quad$ Completely normal muscle, no fatty streak

Muscle contains some fatty streak

Fatty streak significant 3) Post but muscle $>$ fat

$3 \quad$ Fat $=$ Muscle

$4 \quad$ Fat $>$ Muscle

1) Stage $1 \& 2$ has best prognosis 2) Fatty infiltration of infraspinatus can become severe, with severe functional impairment

Table 7: Thomazeau's Classification on Muscle Occupancy

\begin{tabular}{|c|c|c|c|c|c|c|}
\hline \multicolumn{2}{|c|}{$\begin{array}{c}\text { Muscle } \\
\text { Atrophy Stage }\end{array}$} & \multicolumn{2}{|c|}{$\begin{array}{l}\text { Occupancy } \\
\text { ratio }\end{array}$} & \multicolumn{2}{|c|}{ Description } & Prognosis \\
\hline \multicolumn{2}{|r|}{1} & \multicolumn{2}{|r|}{$1-0.60$} & \multicolumn{2}{|c|}{$\begin{array}{c}\text { Normal or } \\
\text { slight atrophy }\end{array}$} & Good to excellent \\
\hline \multicolumn{2}{|r|}{2} & \multicolumn{2}{|c|}{$0.60-0.40$} & \multicolumn{2}{|c|}{$\begin{array}{l}\text { Moderate } \\
\text { Atrophy }\end{array}$} & Good to excellent \\
\hline \multicolumn{2}{|r|}{3} & \multicolumn{2}{|r|}{$<0.40$} & \multicolumn{2}{|c|}{$\begin{array}{l}\text { Severe } \\
\text { Atrophy }\end{array}$} & $\begin{array}{c}\text { Fair- difficult } \\
\text { surgically with } \\
\text { unreliable results }\end{array}$ \\
\hline \multicolumn{7}{|c|}{ Table 8: Hamada's Classification } \\
\hline Grade & $\begin{array}{r}\text { Acromio } \\
\text { Humeral } \\
\text { Interval (A }\end{array}$ & & $\begin{array}{c}\text { Gleno- } \\
\text { Humeral } \\
\text { Joint }\end{array}$ & $\begin{array}{c}\text { Rotator- } \\
\text { Cuff/LHB } \\
\text { Tear }\end{array}$ & & Remarks \\
\hline 1 & $>6 \mathrm{~mm}$ & & Normal & $\begin{array}{l}\text { Massive with } \\
\text { LHB intact }\end{array}$ & \multirow{5}{*}{\multicolumn{2}{|c|}{$\begin{array}{c}\text { 1) Grade } 1 \text { and } 2 \text { - Joint } \\
\text { preserving procedure better } \\
\text { 2) Grade } 4 \text { and 5, reverse } \\
\text { shoulder arthroplasty better } \\
\text { 3) Walch Modification- } \\
\text { Grade } 4 \text { subdivided into 4A- } \\
\text { Acetabulization absent } \\
\text { and 4B- Acetabulization } \\
\text { present }\end{array}$}} \\
\hline 2 & $<5 \mathrm{~mm}$ & & Normal & $\begin{array}{l}\text { Massive with } \\
\text { LHB tear }\end{array}$ & & \\
\hline 3 & Acetabulizat & tion & Normal & $\begin{array}{l}\text { Massive with } \\
\text { LHB tear }\end{array}$ & & \\
\hline 4 & Acetabulizat & tion & Narrowed & $\begin{array}{l}\text { Massive with } \\
\text { LHB tear }\end{array}$ & & \\
\hline 5 & \multicolumn{2}{|c|}{ Acetabulization } & $\begin{array}{l}\text { Humeral } \\
\text { Head } \\
\text { Collapsed }\end{array}$ & $\begin{array}{l}\text { Massive with } \\
\text { LHB tear }\end{array}$ & & \\
\hline
\end{tabular}

determine the tear pattern and repair technique. After a tear pattern is established, temporary reduction is done using a grasper. This helps to evaluate the quality of the tissue, tendon mobility and suture-holding property prior to choosing the appropriate repair technique.

\section{Discussion}

Rotator cuff lesions are one of the most common pathologies encountered in day-to-day clinical practice. However, there is no consensus regarding the classification system that is crucial in deciding the treatment options. With advancements in arthroscopy techniques, implants and high-resolution MRI investigations, the management options for rotator cuff tears has evolved. Options can now include procedures that are non-operative, open or arthroscopic in nature.

After a detailed clinical examination of the patient's shoulder, the surgeon needs to classify lesions based on X-ray and MRI before deciding on the treatment option. For classifying the tear depth, the senior author prefers to use the Ellman classification [1]. There is consensus regarding whether the partial tear is articular-sided or bursalsided. Although Ellman himself classified the tear depth arthroscopically, Spencer et al [11] classified the tears based on MRI. The ease of use of this method, a " $50 \%$ rule", despite the lack of 


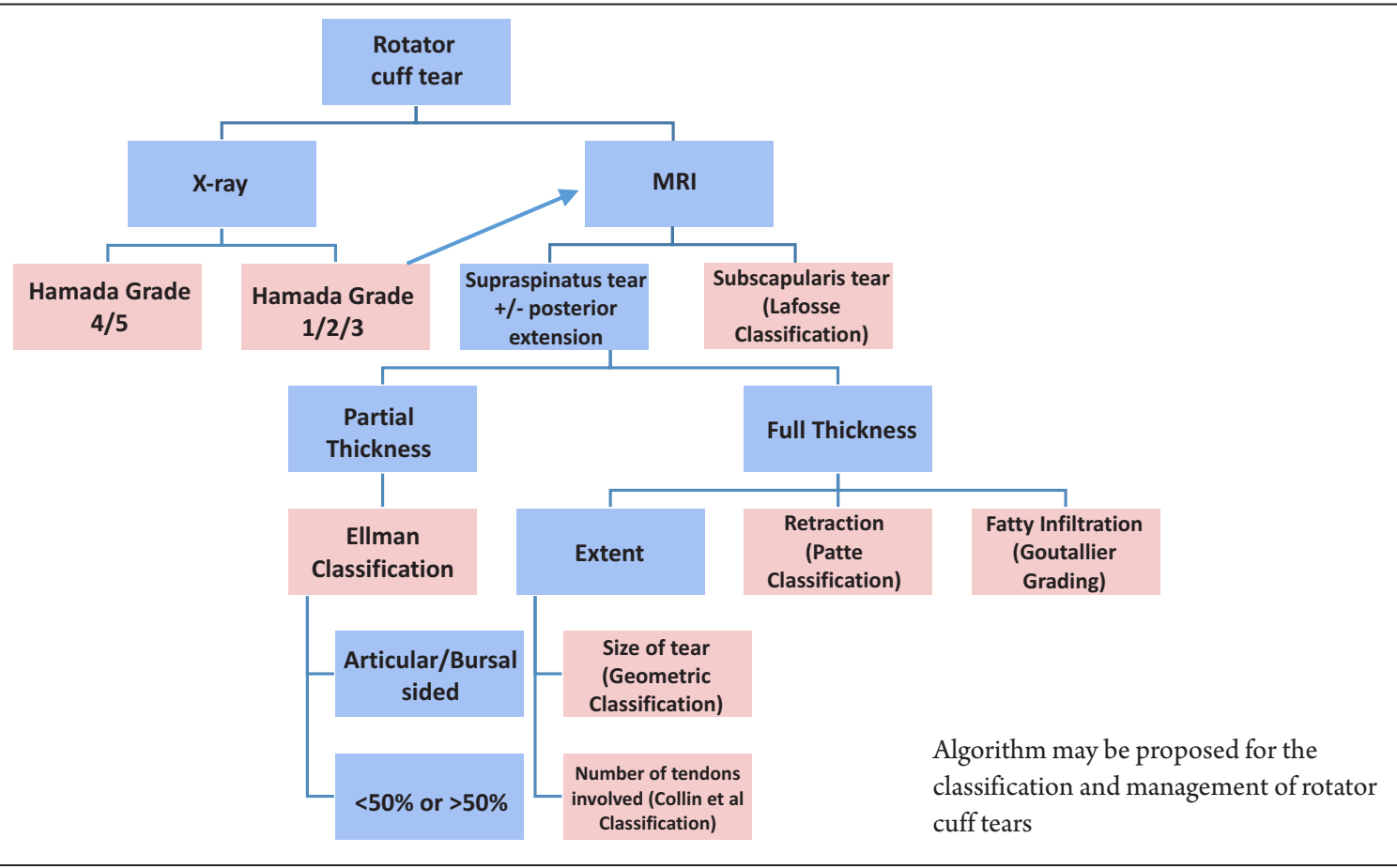

published clinical or biomechanical study, makes it popular among surgeons.

With regards to the extent, the geometric classification of tears by Davidson et al [2] using preoperative MRI remains the preferred classification as it helps to predict the shape of tear, plan the repair and assess prognosis before entering the operating theatre. Once the size and pattern of the tear is established, it is important to note the number of tendons involved. There have been many classifications regarding this $[3,4,12,24]$. The classification given by Collin et al is the only one that correlates the extent of the lesion to the loss of range of motion. Hence the senior author prefers the geometric classification and the Collin classification for determining the extent of the tear.

When subscapularis tears are present, the senior author prefers the Lafosse classification [5]. It is also important to look for subluxation or lesions in the long head of biceps tendon in cases with subscapularis tears. Non-addressal of partial or subtle subscapularis tears or biceps tendon lesions are a common cause of persistent postoperative anterior shoulder pain in rotator cuff repair patients [26].

Regarding the retraction of the tendon cuff, the classification proposed by Patte [3] in 1990 remains the gold standard with extremely high prognostic significance. This has been followed by surgeons for many years including the senior author.

Assessment of muscle atrophy and fatty infiltration is one of the most important factors to determine prognosis. Increased fatty infiltration indicates poor suture holding capacity and hence, higher retear rates. Goutallier grading [6] was based on CT scan done on patients preoperatively and postoperatively. With the advent of improved MRI technology, the same grading is now followed for lateral parasagittal images where the scapular spine is in contact with the scapular body [7]. A quick and reliable method - the "tangent sign" in the sagittal plane - can be followed to assess the atrophy in supraspinatus muscle belly [8]. However, Laderman et al [13] points out that there can be an overestimation of the fatty infiltration in the sagittal images (Y view) due to excess musculotendinous retraction. This information should be kept in mind by the radiologists while assessing muscle bellies on both the axial and sagittal views with sufficiently medial cuts to allow proper assessment regardless of the retraction.

Progression of the massive rotator cuff tears leads to rotator cuff arthropathy which is classified according to Hamada et al [21]. Once arthritic changes set in, repair becomes a non-viable option. Reverse shoulder arthroplasty has become the preferred management for patients with rotator cuff arthropathy [14].

Massive irreparable tears require a special mention. Cofield et al [18] described a massive tear as greater than $5 \mathrm{~cm}$, while others consider a massive rotator cuff tear to be one involving two or more tendons. Posterosuperior tears are more common (involving the supraspinatus and infraspinatus) compared to anterosuperior tears (involving the supraspinatus and subscapularis tendons). The size and reparability of a tear are not always related, nor are they mutually exclusive [15].

An irreparable rotator cuff tear may be defined as a tear where direct tendon-to-bone repair is not possible despite adequate tissue mobilization. Some authors suggest that up to $30 \%$ of total rotator cuff tears can be classified as "irreparable tears" [15-17]. Based on the classification systems followed by the senior author, an irreparable tear may fall under the following categories:

1. Extent oflesion -

a. Geometric classification Type 3 and 4

b. Collin et al Classification Type B, C and E

2. Retraction of Proximal Stump - Patte Type 3

3. Fatty Infiltration - Goutallier Grade 3 or 4

4. Progression - Hamada Grade 3 and above

However, the true determination of an irreparable tear is done only during surgery.

Options for such tears could be (1) Conservative, (2) Arthroscopic decompression, (3) Partial Repair, (4) Complete repair, (5) Graft Augmentation, (6) Tendon Transfer, (7) Superior Capsular Reconstruction, (8) Biodegradable Subacromial Spacer Insertion, (9) Arthroplasty [15]. While no singular gold standard treatment exists in these challenging cases, the optimal treatment depends on a patient's functional status as well as the skill and procedural familiarity of the 
surgeon $[15,16]$.

Based on current literature, an algorithm may be proposed for the classification and management of rotator cuff tears.

\section{Conclusion}

No single classification exists at present that takes all the factors involved in making management decisions for rotator cuff lesions into account. This is because many factors are involved in deciding what the appropriate treatment for that patient is, as well as the prognostication and prediction of the outcome. Therefore, we must use a combination of classification systems to both communicate and compare our results. This includes tear thickness, extent, retraction and fatty infiltration. The authors in this paper aim to provide a review of the classification systems that are followed in day-to-day practice and help to arrive at a logical conclusion while making decisions for this frequently encountered pathology.

\section{References}

1. Ellman H. Diagnosis and treatment of incomplete rotator cuff tears. Clin Orthop Relat Res. 1990;(254):64-74.

2. Davidson J, Burkhart SS. The Geometric Classification of Rotator Cuff Tears: A System Linking Tear Pattern to Treatment and Prognosis. Arthrosc - J Arthrosc Relat Surg [Internet]. 2010;26(3):417-24. Available from: http://dx.doi.org/10.1016/j.arthro.2009.07.009

3. Patte D. Classification of rotator cuff lesions. Clin Orthop Relat Res. 1990;(254):81-6.

4. Collin P, Matsumura N, Lädermann A, Denard PJ, Walch G. Relationship between massive chronic rotator cuff tear pattern and loss of active shoulder range of motion.J Shoulder Elb Surg. 2014;23(8):1195-202.

5. Lafosse L, Jost B, Reiland Y, Audebert S, Toussaint B, Gobezie R. Structural integrity and clinical outcomes after arthroscopic repair of isolated subscapularis tears.JBoneJtSurg-Ser A. 2007;89(6):1184-93.

6. Goutallier D, Postel JM, Bernageau J, Lavau L, Voisin MC. Fatty muscle degeneration in cuff ruptures: Pre- and postoperative evaluation by CT scan. Clin Orthop Relat Res. 1994; (304):78-83.

7. Fuchs B, Weishaupt D, Gerber C, Hodler J. Scheduled Tomography for. :599-605.

8. Zanetti M, Gerber C, Hodler J. Quantitative assessment of the muscles of the rotator cuff with magnetic resonance imaging. Invest Radiol. 1998;33(3):163-70.

9. Thomazeau H, Rolland Y, Lucas C, Duval J, Langlais F. Atrophy of the supraspinatus belly. Acta Orthop. 1996;67(3):264-8.

10. Brolin TJ, Updegrove GF, Horneff JG. Classifications in Brief: Hamada Classification of Massive Rotator Cuff Tears. Clin Orthop Relat Res. 2017;475(11):2819-23.

11. Spencer EE, Dunn WR, Wright RW, WolfBR, Spindler KP, McCarty E, et al. Interobserver agreement in the classification of rotator cuff tears using magnetic resonance imaging. Am J Sports Med.2008;36(1):99-103.

12. Habermeyer P, Magosch P, Lichtenberg S. Classifications and scores of the shoulder. Classifications and Scores of the Shoulder. 2006.1-297p.

13. Lädermann A, Burkhart SS, Hoffmeyer P, Neyton L, Collin P, Yates E, et al. Classification of full-thickness rotator cuff lesions: A review. EFORT Open Rev. 2016;1(12):420-30.

14. Brolin TJ, Updegrove GF, Horneff JG. Classifications in Brief: Hamada Classification of Massive Rotator Cuff Tears. Clin Orthop Relat Res. 2017;475(11):2819-23.
15. Juhan T, Stone M, Jalali O, Curtis W, Prodromo J, Weber AE, et al. Irreparable rotator cuff tears: Current treatment options. Orthop Rev (Pavia). 2019;11(3):123-8.

16. Neri BR, Chan KW, Kwon YW. Management of massive and irreparable rotator cuff tears. J Shoulder Elb Surg [Internet]. 2009;18(5):808-18. Availablefrom: $h$ ttp://dx.doi.org/10.1016/j.jse.2009.03.013

17. Oh JH, Park MS, Rhee SM. Treatment strategy for irreparable rotator cuff tears. CiOS Clin Orthop Surg. 2018;10(2):119-34.

18. DeOrio JK, Cofield RH: Results of a second attempt at surgical repair of a failed initial rotator-cuff repair.J Bone Joint Surg Am 1984;66(4):563-567

19. Kissenberth MJ, Rulewicz GJ, Hamilton SC, Bruch HE, Hawkins RJ. A positive tangent sign predicts the repairability of rotator cufftears. J Shoulder Elbow Surg 2014;23:1023-1027

20. Neer CS 2nd, Cruess RL, Sledge CS, Wilde AH. Total glenohumeral replacement: a preliminary report. Orthop Trans. 1977;1:244-245

21. Hamada K, Fukuda H, Mikasa M, Kobayashi Y. Roentgenographic findings in massive rotator cufftears: a long-term observation. Clin Orthop Relat Res. 1990;254:92-96

22. Walch G, Edwards B, Boulahia A, Nove-Josserand L, Neyton L, Szabo I. Arthroscopic tenotomy of the long head of the biceps in the treatment of rotator cuff tears: clinical and radiographic results of 307 cases. J Shoulder Elbow Surg. 2005; 14:238-246.

23. Burkhart SS: Fluoroscopic comparison of kinematic patterns in massive rotator cuff tears: A suspension bridge model. Clin Orthop Relat Res 1992;284:144-152

24. Gerber C, Fuchs B, Hodler J. The results of repair of massive tears of the rotator cuff.J Bone Joint Surg [Am] 2000;82-A:505-515

25. Neviaser TJ, Neviaser RJ, Neviaser JS, Neviaser JS. The four-in-one arthroplasty for the painful arc syndrome. Clin Orthop Relat Res. 1982;(163):107-112

26. APA Nho, Shane J. MD, MS; Strauss, Eric J. MD; Lenart, Brett A. MD; Provencher, Matthew T. MD, MC, USN; Mazzocca, Augustus D. MD, MS; Verma, Nikhil N. MD; Romeo, Anthony A. MD Long Head of the Biceps Tendinopathy: Diagnosis and Management, American Academy of Orthopaedic Surgeon: November 2010-Volume 18 -Issue 11 - p 645-656

27. Pedowitz RA, Higashigawa K, Nguyen V: The "50\% rule" in arthroscopic and orthopaedic surgery. Arthroscopy 2011;27(11):1584-1587

\section{Conflict of Interest: NIL} Source of Support: NIL

\section{How to Cite this Article}

Chidambaram R, Mukhopadhyay R |Classification Systems in Rotator Cuff Tears | Asian Journal of Arthroscopy | January-June 2021; 6(1):31-35. 